\title{
Membrane Effects of Pronethalol on the Mammalian Heart Muscle Fiber
}

\author{
Koki Shigenobu,* Akimitsu Kamiyama, M. D., ** Keijiro Takagi, Ph. D., * \\ and Kojiro Matsuda, M.D.**
}

GINCE Black and Stephenson ${ }^{11}$ reported the beta-adrenergic blockade $D$ with pronethalol, many reports have appeared concerning its antiarrhythmic action. Murray, et al. ${ }^{91}$ demonstrated that pronethalol markedly depressed the sensitivity of myocardium to the arrhythmia induced by epinephrine in hydrocarbon anaesthesia. Pronethalol is also reported to depress the arrhythmias induced by cardiac glycosides. ${ }^{3)}$ Stock and Dale ${ }^{14)}$ have reported that pronethalol effectively suppressed digitalis-induced arrhythmias in 7 human subjects.

Recently, some notable advances have been made in electrophysiological techniques, permitting a detailed study on the mode of action of the antiarrhythmics. And although the effects of quinidine and procaine amide have been studied in some detail, ${ }^{10), 19)}$ there is no systematic electrophysiological investigations about the antiarrhythmic actions of pronethalol.

The present study was performed to investigate the electrophysiological basis of its antiarrhythmic action.

\section{METHOD}

To observe the electrical activity of single cardiac muscle fiber, the intracellular microelectrode was used. ${ }^{7}$ Preparations were obtained from right ventricle or atrium of the dog. The preparation was fixed on a paraffin block in the bath containing $35 \mathrm{ml}$. of Tyrode's solution, maintained at $37^{\circ} \mathrm{C}$ and circulated by bubbled oxygen.

The driving electrodes used were a pair of $\mathrm{Ag}-\mathrm{AgCl}$ wires inserted into the preparation at its edge. The resistances of the recording glass microelectrodes filled with $3 \mathrm{M}-\mathrm{KCL}$ ranged from 5 to 15 megohms.

Stock solution of pronethalol*** was prepared by dissolving the crystalline material at the concentration of $10^{-3} \mathrm{Gm} . / \mathrm{ml}$. This stock solution was applied into the bath solution by means of a fine needle attached to syringe. The concentrations given in text are the final values, in Gm. per ml. of solutions.

\footnotetext{
* From the Department of Chemical Pharmacology, Faculty of Pharmaceutical Sciences, University of 'lokyo, Bunkyo-ku, Tokyo.

** Department of Physiology, Faculty of Medicine, University of Tokyo, Bunkyo-ku, Tokyo.

*** Pronethalol used was synthetized in the Department of Chemical Pharmacology, Faculty of Pharmaceutical Sciences, University of Tokyo.

Received for publication May 4, 1966.
} 


\section{Results}

1) Effects of pronethalol on the pacemaker cell

Effects of pronethalol on the pacemaker activity of the right bundle branch of the dog were as follows. The lowest concentration of pronethalol to produce reduction of the pacemaker rate was $10^{-6}$ (Fig. 1). This depressant effect was mainly due to the reduction of the slow depolarization rate of

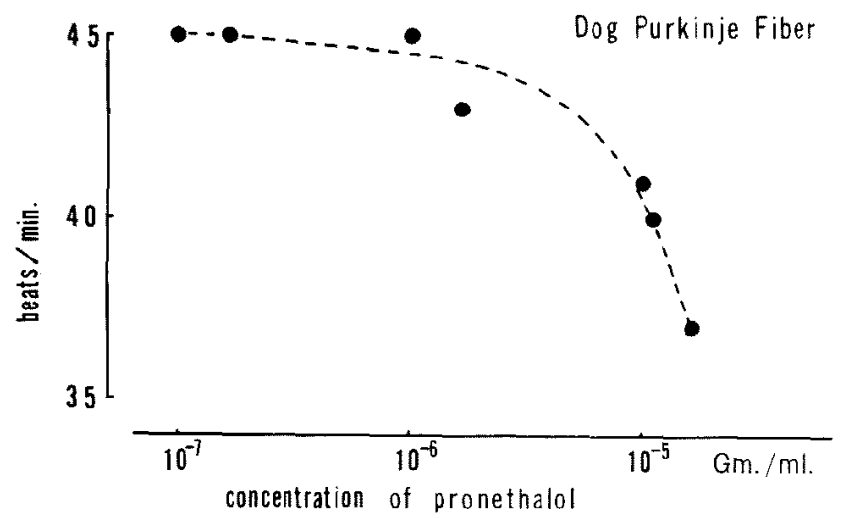

Fig. 1. Decrease in pacemaker rate with the concentration of pronethalol. Dog right bundle branch. Abscissa : concentration of pronethalol in logarithmic scale; ordinate: pacemaker rate.

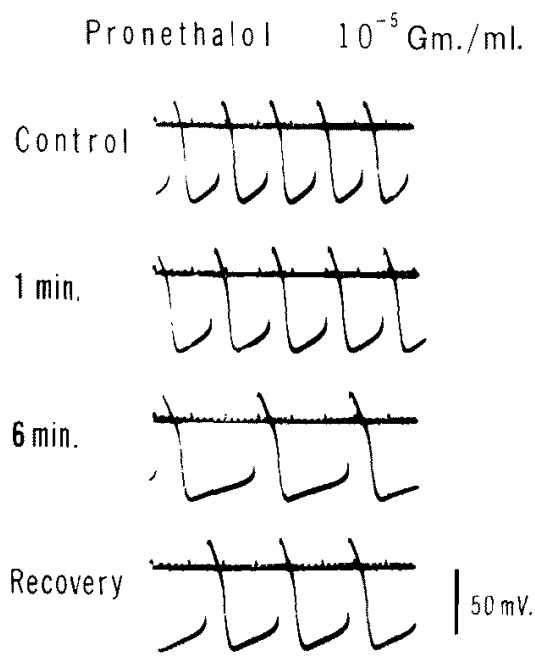

Dog Purkinje Fiber

Fig. 2. Pacemaker potential of dog right bundle branch. Effect of pronethalol. Time: $100+500$ msec. 
pacemaker potential (Fig. 2). The same effects of pronethalol were also observed in the sinus node cell of the rabbit.

2) Inhibition of the multiple responses

The multiple responses could be caused by application of strong square current-pulse of about 5 msec. duration to the preparation via extracellular electrodes in the so-called vulnerable period. ${ }^{2)}$ This multiple responses could be induced over and over again both on the atrium and on the ventricle. This responses completely disappeared after the administration of pronethalol at

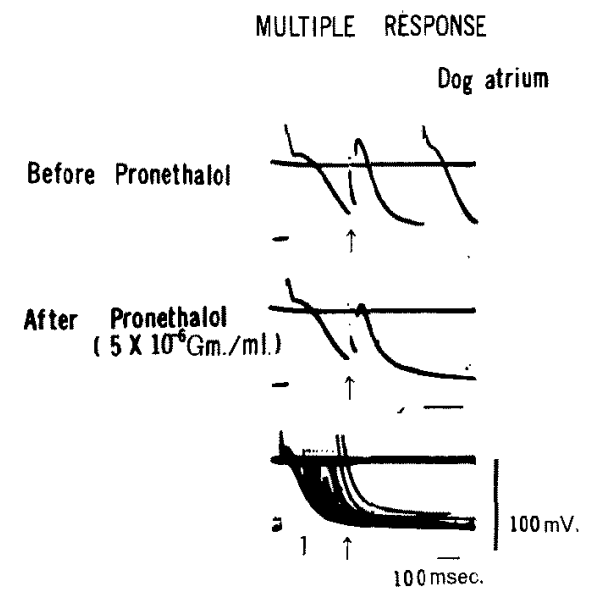

Fig. 3. Multiple responses induced by extracelluiar currentpulse (arrow) in the atrial fiber. Effect of pronethalol. In the lowest trace, stimulations were applied in various phases between two arrows. The effect of each stimulation was superimposed.

MULTTPLE RESPONSE

Dog Purkinje Fiber

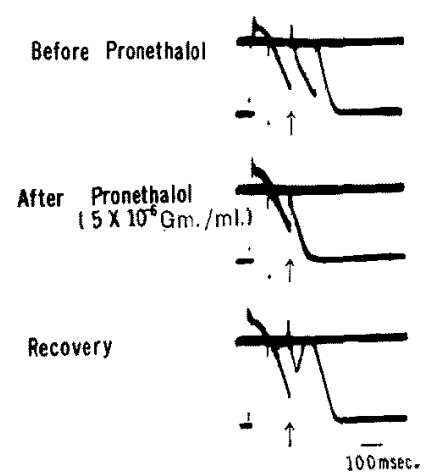

Fig. 4. Multiple responses induced by extracellular current-pulse (arrow) in the terminal Purkinje fiber. Effect of pronethalol. 
the concentration of $5 \times 10^{-6}$ (Fig. 3 and Fig. 4). After pronethalol, the multiple responses could never be induced in any phase of action potential (Fig. 3).

3) The shape of action potential

Pronethalol at the concentration of $5 \times 10^{-6}$ did not affect so much on the shape of action potential of the terminal Purkinje fiber. A slight shortening of the plateau was a sole finding (Fig. 5). But at the concentration of $10^{-5}$, the duration of the plateau decreased considerably and the resting potential was slightly reduced. The overshoot of the spike was also markedly depressed. These effects were similarly observed also in the auricular fiber as well as in the ventricular proper muscle.

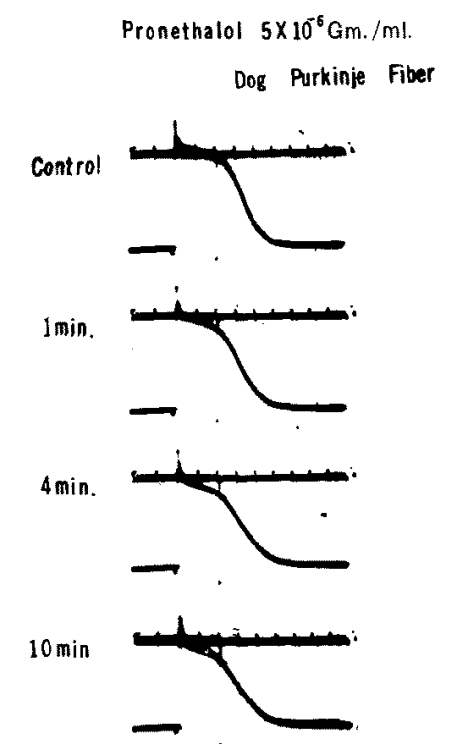

Fig. 5. Shapes of action potential recorded from terminal Purkinje fiber of dog right ventricle. Calibration: $-100 \mathrm{mV}$. downward from extracellular level. Time : $10+50 \mathrm{msec}$.

\section{4) Prolongation of the refractory period}

Test shocks were applied to the fiber under observation through another intracellular microelectrode which was inserted closely to the recording electrode at various periods of the repolarization phase of action potential, and the strength-interval curve (excitability-recovery curve in the refractory period) was obtained. After administration of pronethalol $\left(5 \times 10^{-6} \mathrm{Gm} . / \mathrm{ml}\right.$.), the recovery curve shifted to the right (Fig. 6), indicating that pronethalol prolonged the refractory period, by about $25 \mathrm{msec}$. in absolute and about $100 \mathrm{msec}$. in relative on the average of 6 experiments. The prolongation of relative refractory period seems to be the outstanding feature. The diastolic 


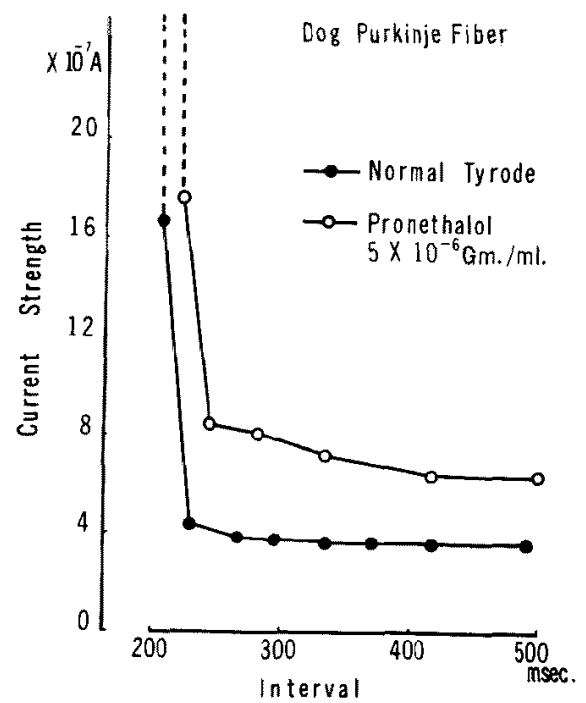

Fig. 6. Strength-interval curve. Refractory period, especially relative, prolonged after pronethalol.

threshold was elevated in all cases tested as can be seen in the example in Fig. 6 .

5) Conduction velocity

The measurement of the conduction velocity was made on the Purkinje

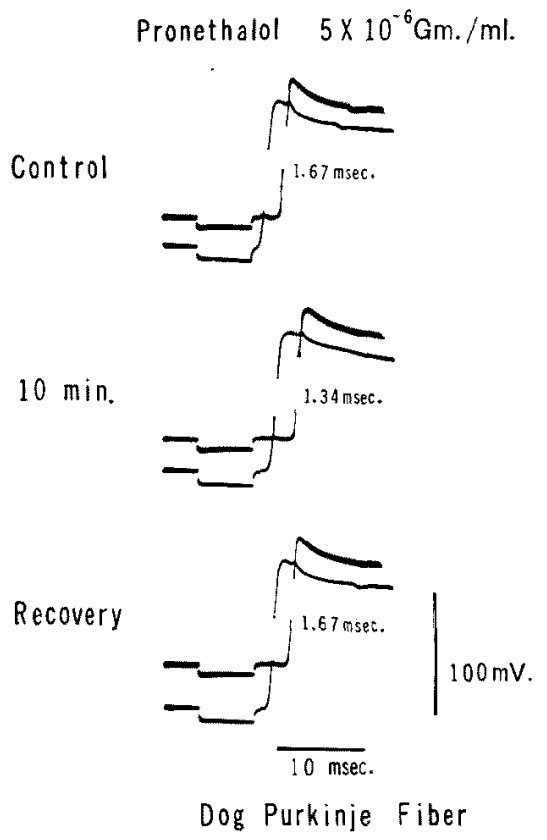

Fig. 7. Effect of pronethalol on the conduction velocity. After pronethalol, conduction velocity of impulse decreased. 


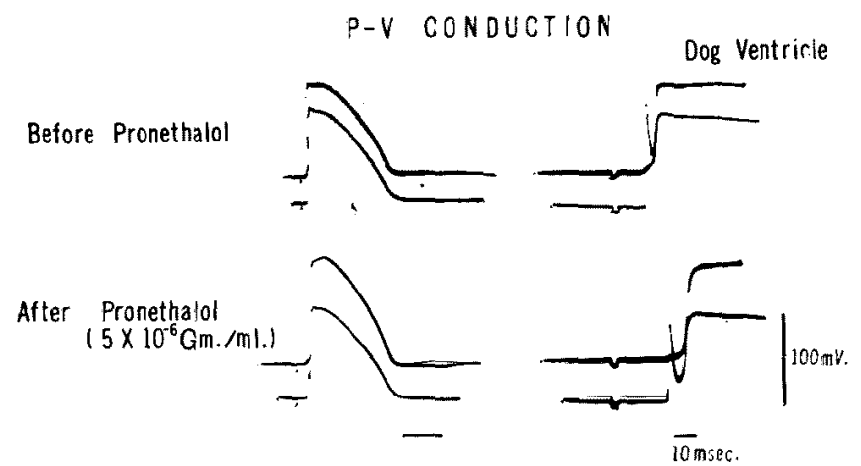

Fig. 8. Effect of pronethalol on the conduction velocity between terminal Purkinje fiber and ventricular fiber. In each tracing, lower record shows terminal Purkinje fiber having a deep incision in the rising phase, and upper ventricular fiber adjacent to terminal Purkinje fiber. Right side shows tracing at high speed sweep. P.V conduction delayed markedly after pronethalol.

fiber (Fig. 7) from the distance between the 2 sites of microelectrode recording and the delay of latencies to excitation. While the conduction velocity was $1.67 \mathrm{M} . / \mathrm{sec}$. in the control, it decreased to $1.34 \mathrm{M} . / \mathrm{sec}$. after the administration of pronethalol (concentration : $5 \times 10^{-6} \mathrm{Gm} . / \mathrm{ml}$.). The change was well reversible after the drug was washed out.

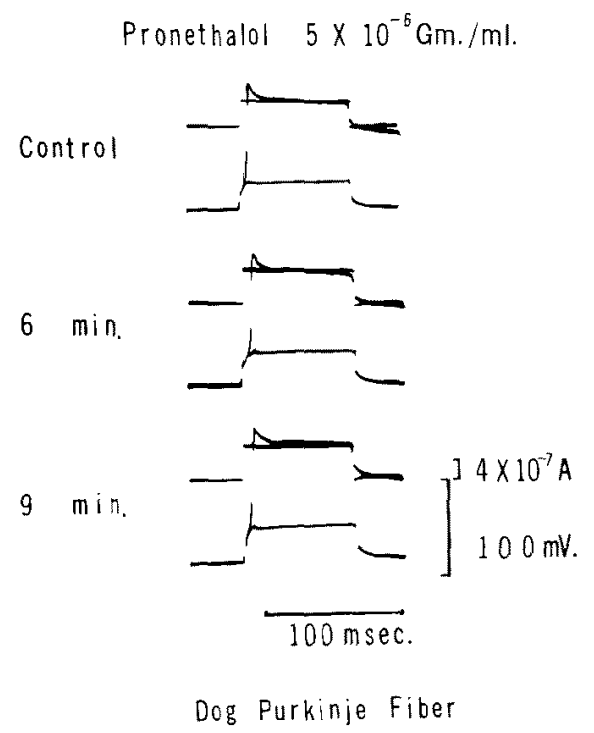

Fig. 9, Change in critical membrane potential. Depolarization is induced in the diastolic phase between 2 driven action potentials. Both of critical depolarizations which are effective and not effective in producing fullsized action potential are shown superimposed. Polarizing current was monitored above in each tracing. 
The conduction delay from the terminal Purkinje fiber to the ventricular muscle, which was estimated by the time interval between the first and second rises of depolarization of action potential of the terminal Purkinje fiber, ${ }^{8)}$ became more conspicuous under pronethalol (Fig. 8).

6) Critical membrane potential

The critical membrane potential and threshold current were measured also by intracellular stimulation. The critical membrane potential was changed by pronethalol from $-60 \mathrm{mV}$. in control to $-52 \mathrm{mV}$. as shown in the example of Fig. 9.

7) The rate of rise of action potential

The effect of pronethalol on the maximum depolarization rate was measured by recording the first differential of depolarizing potential in the Purkinje fiber. Pronethalol depressed significantly the maximum depolarization rate. The rate of rise of action potential, which was $490 \mathrm{~V} . / \mathrm{sec}$. in the normal Tyrode's solution, was reduced by pronethalol $\left(5 \times 10^{-6} \mathrm{Gm} . / \mathrm{ml}\right.$.) to $430 \mathrm{~V} . / \mathrm{sec}$. after $1 \mathrm{~min}$. and to $310 \mathrm{~V}$./sec. after $5 \mathrm{~min}$. (Fig. 10).

By plotting the relationship between the resting potential which was modified artificially by intracellular polarization and the rate of rise of action potential, the Na-inactivation curve could be obtained. After the application

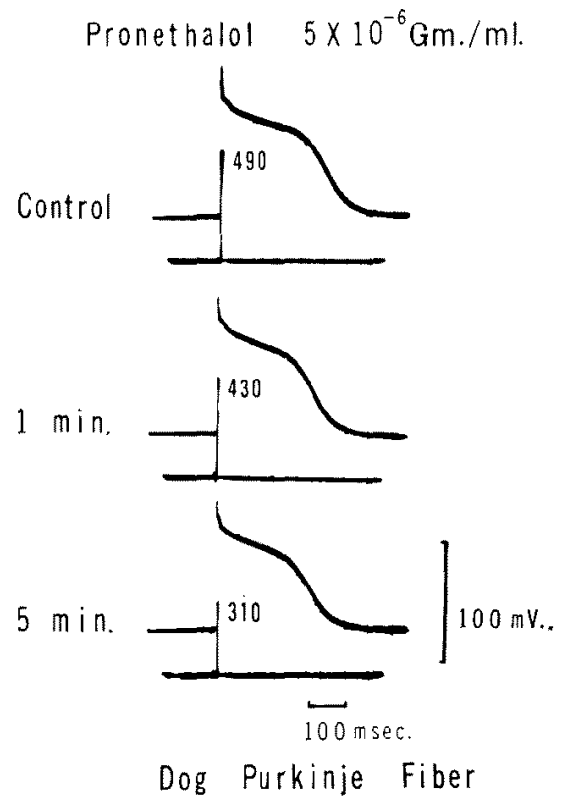

Fig. 10. Effect of pronethalol on the maximum depolarization rate. Each number indicates the maximum depolarization rate in $\mathrm{V} . / \mathrm{sec}$. measured from the first-ordered derivative of spike shown under the action potential. 


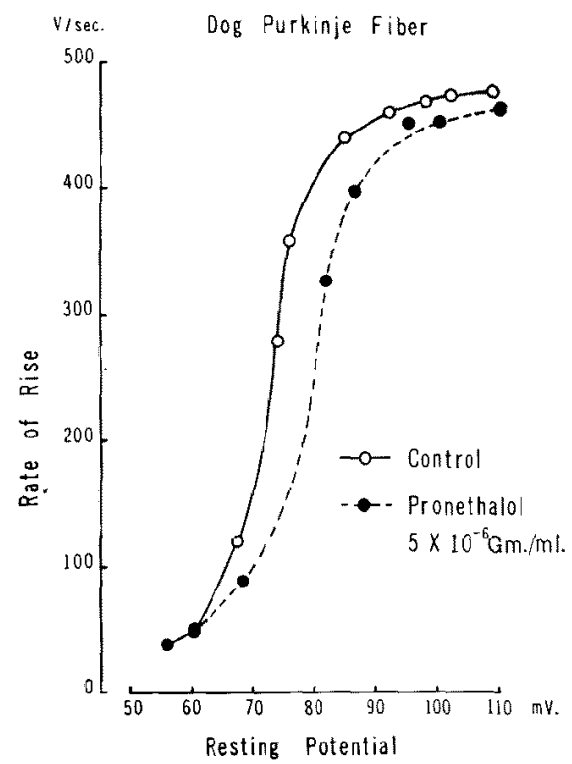

Fig. 11. Effect of pronethalol on Na-inactivation curve.
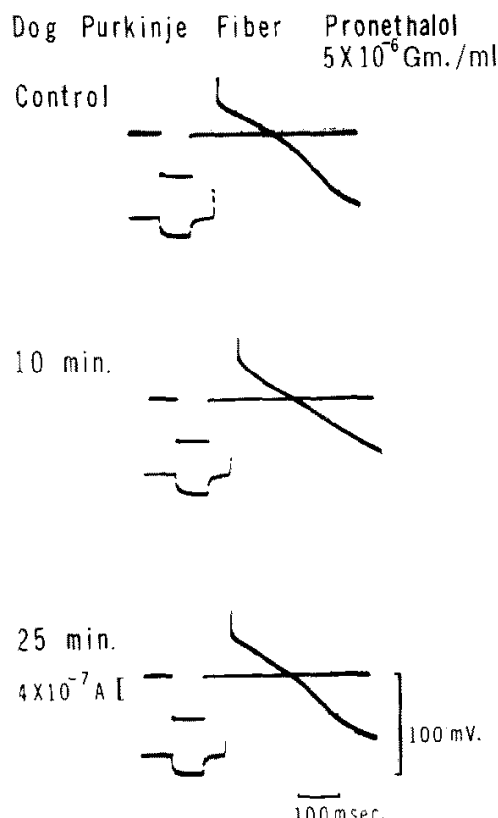

Fig. 12. Change of membrane resistance. Amplitude of electrotonic potential at resting state between repetitive action potential is observed. Applied anodal current was monitored above in each tracing. 
of pronethalol $\left(5 \times 10^{-6} \mathrm{Gm} . / \mathrm{ml}\right.$ ), this curve shifted to the right, indicating a probable inactivation of the $\mathrm{Na}$-carrier system by pronethalol (Fig. 11).

\section{8) The membrane resistance}

The effect of pronethalol on the membrane resistance was observed in the resting state and plateau phase by measuring the amplitude of electrotonic potential which was induced by the hyperpolarizing current with constant strength. Up to the concentration of $5 \times 10^{-6}$, pronethalol showed no effect on the membrane resistance both in the resting and plateau phases (Fig. 12).

\section{Discussion}

Pronethalol has been reported to prevent various experimental cardiac arrhythmias, e.g., extrasystoles and ventricular fibrillation induced by epinephrine combined with hydrocarbon anaesthesia, ${ }^{9)}$ and by cardiac glyco-

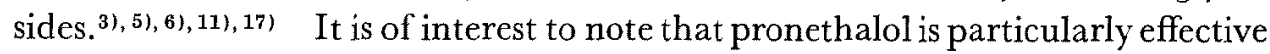
on the ventricular fibrillation. And the antiarrhythmic activity of pronethalol is also reported in clinical applications. The present investigation gave evidence in the single fibers of auricle and ventricle for its effectiveness in controlling the induced multiple responses.

The present investigation revealed that the electrophysiological mechanisms of the antiarrhythmic activity of pronethalol were i) depression of pacemaker activity (decrease in the heart rate), ii) prolongation of the refractory period, especially of the relative refractory period, iii) reduction of the critical membrane potential, iv) depression of the conduction velocity, particularly in the P-V conduction. At the concentrations to produce the above mentioned effects, pronethalol produced no significant changes in the resting potential and in the shape of action potential.

In the present study it was also shown that pronethalol did not modify the resting potential as well as the membrane resistance in the resting and active phases. These facts seem to indicate that pronethalol has no definite influence on potassium permeability.

On the other hand, the rate of rise of the action potential was depressed and the Na-inactivation curve shifted to the right (as shown in Fig. 11) by pronethalol, indicating inhibition of the Na-carrier system. ${ }^{18)}{ }^{19}$ ) These observations agree with that of Vaughan-Williams. ${ }^{121,16)}$ And above mentioned various electrophysiological properties of pronethalol (prolongation of refractory period, depression of conduction velocity, and decrease in pacemaker activity) are to be explained from the depression of the active inward current carrier system. 
Investigations on quinidine, ${ }^{10)}$ procaine amide and cocaine ${ }^{19)}$ have been carried out and their antiarrhythmic activities were considered to be due to inhibition of Na-carrier system. The mechanism of the antiarrhythmic action of pronethalol is similar to those of these well-known antiarrhythmics. Pronethalol has also a local anaesthetic action, and its effectiveness is of the same degree as butacaine. ${ }^{6)}$

Many have discussed the interaction between the beta-adrenergic receptor blockade and the antiarrhythmic action of pronethalol. Murray, et al. ${ }^{91}$ showed remarkable depression by pronethalol of the sensitivity of the myocardium to the arrhythmia induced by epinephrine with hydrocarbon anaesthesia, and suggested a certain implication of beta-adrenergic receptors in the development of the epinephrine induced arrhythmias. According to Sekiya and Vaughan-Williams ${ }^{11,17)}$ and Erlij and Mendez ${ }^{31}$ the depressive action of pronethalol upon ouabain induced arrhythmias is considered to be associated with the $b e t a$-blocking activity of pronethalol.

Lucchesi ${ }^{5}$ suggested that the antiarrhythmic action of pronethalol could not be explained entirely by its beta-blocking action, because he could not find parallelism between the beta-blocking and the antiarrhythmic activities of pronethalol. Somani and Lum $^{13)}$ who observed that the beta-adrenergic blocking agent, $\mathrm{N}$-isopropyl-p-nitrophenyl-ethanolamine, did not depress the ouabain induced arrhythmia, suggested the independence of its antiarrhythmic action from the beta-blocking action. Lucchesi demonstrated that the dextro isomer of pronethalol possessed a strong depressive action upon the arrhythmias induced by epinephrine or by ouabain in spite of its lack of the beta-adrenergic blocking activity. ${ }^{61}$

Trautwein and Schmidt ${ }^{15}$ and Kassebaum ${ }^{4}$ ) who studied on the effects of epinephrine upon the ionic mechanisms in the membrane, concluded that epinephrine does alter neither gK nor active $\mathrm{gNa}$, but increases the steadystate gNa. The effects of pronethalol as revealed in the present investigation are not antagonistic to the effects of epinephrine as stated above. The negative chronotropic activity of pronethalol as evidenced by the depression of pacemaker potential was not modified by reserpinization.

It may be concluded that the antiarrhythmic action of pronethalol is mainly due to depression of the active inward current carrier system, but not due to the beta-blocking action, as far as the electrophysiological evidences reported here are concerned.

\section{Summary}

Actions of pronethalol on the electrophysiological properties of the mam- 
malian heart muscle were investigated. Pronethalol decreased the pacemaker activity of the ventricle (right bundle branch of dog) and of the sinus node (rabbit). Conduction velocity, critical membrane potential and maximum depolarization rate were all reduced by pronethalol. Absolute and relative refractory period were prolonged, and Na-inactivation curve shifted to the right (inhibition of Na-carrier system) by pronethalol, whereas no or little effects, if any, were observed on the resting potential and membrane resistance in resting and acting phases.

The mechanism of antiarrhythmic action of pronethalol was discussed, and it was concluded that the mechanism is not the same as that for the wellknown beta-blocking action of pronethalol.

\section{REFERENCES}

1. Black, J. W. and Stephenson, J. S.: Lancet ii : 311, 1962.

2. Brooks, C., Hoffman, B. F., Suckling, E. E., and Orias, O.: Excitability of the heart, Grune and. Stratton, Inc., p. 136, 1955.

3. Erij, D. and Mendez, R.: J. Pharmacol. 144 : 97, 1964.

4. Kassebaum, D. G.: Proc. of the 2nd Intern. Pharmacol. Meeting, edited by Krayer, O., Pergamon Press, Vol. 5, p. 95, 1964.

5. Lucchesi, B. R.: J. Pharm. $145: 286,1964$.

6. Lucchesi, B. R.: J. Pharm, $148: 94,1965$.

7. Matsuda, K., Hoshi, T., and Kameyama, S. : Seitai no Kagaku 7: 379, 1956 (in Japanese).

8. Matsuda, K., Kamiyama, A., Hoshiyama, M., and Hoshi, T.: J. Physiol. Soc. Jap. 26 : 63, 1964 (in Japanese).

9. Murray, W. J., McKnight, R. L., and Davis, D. A. : Proc. Soc. Exp. Biol. Med. 113 : 439, 1963.

10. Sakurai, K.: J. Physiol. Soc. Jap. 21 : 990, 1959 (in Japanese).

11. Sekiya, A. and Vaughan-Williams, E. M.: Brit. J. Pharm. 21 : $462,1963$.

12. Sckiya, A. and Vaughan-Williams, E. M. : Brit. J. Pharm. 21 : 481, 1963.

13. Somani, P. and Lum, B. K. B.: J. Pharm. 147: 194, 1965.

14. Stock, J. P. P. and Dale, N.: Brit. Med. J. No. 5367: 1230, 1963.

15. Trautwein, W. and Schmidt, R. F.: Pflügers Archiv, 271: 715, 1960.

16. Vaughan-Williams, E. M.: The mode of action of antifibrillatory drugs, in "Pharmacology of cardiac function", Proc. of the 2nd Intern. Pharmacol. Meeting, edited by Krayer, O., Pergamon Press, Vol. 5, p. 119, 1965.

17. Vaughan-Williams, E. M. and Sekiya, A.: Lancet ii : 420, 1963.

18. Weidmann, S.: J. Physiol. $127: 213,1955$.

19. Weidmann, S.: J. Physiol. $129: 568,1955$. 